\title{
Success Factors and Barriers in Combining Personalized Medicine and Patient Centered Care in Breast Cancer. Results from a Systematic Review and Proposal of Conceptual Framework
}

\author{
Antonio Giulio de Belvis ${ }^{1,2}$, Rossella Pellegrino ${ }^{2, *}$, Carolina Castagna ${ }^{1, *}$, Alisha Morsella ${ }^{1,2}$, Roberta Pastorino $^{1}$ \\ and Stefania Boccia ${ }^{1}$ (D) \\ 1 Department of Life Sciences and Public Health, Section of Hygiene, Università Cattolica del Sacro Cuore, \\ Largo Francesco Vito 1, 00168 Rome, Italy; antonio.debelvis@policlinicogemelli.it (A.G.d.B.); \\ alisha.morsella@unicatt.it (A.M.); roberta.pastorino@unicatt.it (R.P.); stefania.boccia@unicatt.it (S.B.) \\ 2 Clinical Pathways and Outcome Evaluation Unit, Fondazione Policlinico Universitario Agostino Gemelli \\ IRCCS, Via della Pineta Sacchetti 217, 00168 Rome, Italy \\ * Correspondence: rossella.pellegrino96@gmail.com (R.P.); carolina.castagna01@icatt.it (C.C.); \\ Tel.: +39-327-0282-185 (R.P.); +39-338-7838-612 (C.C.)
}

Citation: de Belvis, A.G.; Pellegrino, R.; Castagna, C.; Morsella, A.; Pastorino, R.; Boccia, S. Success Factors and Barriers in Combining Personalized Medicine and Patient Centered Care in Breast Cancer. Results from a Systematic Review and Proposal of Conceptual Framework. J Pers. Med. 2021, 11, 654. https:// doi.org/10.3390/jpm11070654

Academic Editor:

Gianluca Franceschini

Received: 8 June 2021

Accepted: 11 July 2021

Published: 13 July 2021

Publisher's Note: MDPI stays neutral with regard to jurisdictional claims in published maps and institutional affiliations.

Copyright: (c) 2021 by the authors. Licensee MDPI, Basel, Switzerland. This article is an open access article distributed under the terms and conditions of the Creative Commons Attribution (CC BY) license (https:/ / creativecommons.org/licenses/by/ $4.0 /)$.

\begin{abstract}
Breast Cancer (BC) is the leading cause of death due to cancer in women. Ensuring equitable, quality-assured and effective care has increased the complexity of BC management. This systematic review reports on the state-of-the art of available literature investigating the enactment of personalized treatment and patient-centered care models in BC clinical practice, building a framework for the delivery of personalized BC care within a Patient-Centered model. Databases were searched for articles (from the inception to December 2020) reporting on Patient-Centered or Personalized Medicine BC management models, assessing success factors or limits. Out of 1885 records, 25 studies were included in our analysis. The main success factors include clearly defined roles and responsibilities within a multi-professional collaboration, appropriate training programs and adequate communication strategies and adopting a universal genomic language to improve patients' involvement in the decision-making process. Among detected barriers, delays in the use of genetic testing were linked to the lack of public reimbursement schemes and of clear indications in timing and appropriateness. Overall, both care approaches are complementary and necessary to effectively improve BC patient management. Our framework attempts to bridge the gap in assigning a central role played by shared decision-making, still scarcely investigated in literature.
\end{abstract}

Keywords: personalized medicine; Patient Centered Care; breast cancer management; organizational model; systematic review

\section{Introduction}

Among today's major public health concerns, female Breast Cancer (BC) is responsible for an estimated 2.3 million new cases every year, surpassing lung cancer as the most commonly diagnosed cancer $(11.7 \%$ of all cases) and leading cause of death due to cancer in women [1]. Efforts towards guaranteeing standardized, quality-assured and effective care have led to an increasing complexity and specialization of BC management, inevitably backed by an integration of multi-specialist inputs provided collaboratively through the efforts of several healthcare practitioners. Multidisciplinary care in BC, represented by the Breast Unit model, has become the gold-standard of patient-centered BC care and has been included among the determinants for accreditation and funding of facilities, given its capacity to improve patients' quality of life and survival rates [2-4].

Complementarily, advances in diagnosis and treatment have equipped clinical practice with ensembles of newly developed targeted therapies [5] and personalized medicine 
techniques that are gradually improving outcomes and survival, as recent research is equipping specialists with a broader understanding of the biology and heterogeneity of BC, of mechanisms behind tumour resistance and with the possibility of predicting patients' responses to therapies, especially when dedicated clinical governance tools (i.e., molecular tumour boards) are instituted within the care pathway.

Despite such documented progress, literature seems to highlight that the application of such innovations into routine clinical practice is proceeding at a slower pace compared to the generation of such findings [6], stressing the need to concentrate efforts on their implementation into real-life settings.

The aim of this systematic review is two-fold. First, to report on the state-of-the art of available literature investigating the enactment of personalized treatment and patientcentered care models in BC clinical practice. Second, to propose a comprehensive care management framework for the delivery of personalized care to patients with $\mathrm{BC}$, within a patient-centered care model.

\section{Materials and Methods}

This systematic review was conducted and reported according to the Preferred Reporting Items for Systematic Reviews and Meta-Analyses statement [7].

\subsection{Search Strategy}

The electronic databases of Web of Science, PubMed, Scopus were searched to retrieve potential eligible articles, published in English from the inception to December 2020. A Boolean search string was created using the elements of the PICO model ( $\mathrm{P}$, population/patient; I, intervention/indicator; C, comparator/control; and O, outcome).

Furthermore, the search on Scopus was restricted to only humans, English language, "medicine" subject area, document types-articles, reviews, editorials, letters-and publication stage-final articles. Keywords such as "breast cancer management"; "breast units"; "personalized medicine"; "patient centeredness"; "patient-centered care"; "multidisciplinary team"; "tumor board"; "molecular tumor board"; "success factors"; "limits"; "cost effectiveness" were used.

\subsection{Inclusion/Exclusion Criteria}

Articles reporting breast cancer management in terms of patient-centered care and personalized medicine approaches were considered eligible. Studies mainly discussing breast cancer clinical therapeutics, clinical epidemiological data or surgical data were excluded.

For the purpose of our study, we used the European Commission definition, according to which "Personalized medicine" is "A medical model using characterization of individuals' phenotypes and genotypes (e.g., molecular profiling, medical imaging, lifestyle data) for tailoring the right therapeutic strategy for the right person at the right time, and/or to determine the predisposition to disease and/or to deliver timely and targeted prevention" [8].

Similarly, we used the IOM (Institute of Medicine) definition of Patient-Centered care as "care that is respectful of and responsive to individual patient preferences, needs, and values" and that ensures "that patient values guide all clinical decisions" [9].

Relying on Rotter's 2010 Cochrane Review, the key dimensions identified for Patient Centered Care were communication [10], audit/feedback [11], informative systems [12], evidence-based application [13], multidisciplinary approach [14] and education sessions [11]. With regards to Personalized Medicine, on the other hand, the European Council's document of 2015 identifies the molecular board [15], evidence-based genetic testing [16] and shared-clinical decision-making [17]. As such, eligible studies were those fulfilling $t$ the definitions of patient-centered care and/or personalized medicine in terms of inclusion of the aforementioned dimensions.

In parallel, when available, relative key success factors and barriers to implementation of such dimensions were reported. 


\subsection{Study Selection}

After removing duplicate records, four researchers (C.C., A.M., R.P., R.P.) independently screened by title and abstract to outline records according to the inclusion criteria aforementioned. Then, the four researchers performed a full text screening of each article to determine eligibility. Disagreements were resolved through discussion with a fifth researcher (A.G.d.B.).

The reference lists of the included studies were hand-searched to locate additional studies via the snowball search method. The study selection was performed from December 2020 to February 2021.

\subsection{Data Extraction and Synthesis}

Data extraction was conducted by four independent researchers (C.C., A.M., R.P., R.P.) from the end of January to February 2021. A dedicated data extraction form on Excel was used to retrieve the following information for each eligible study:

1. Study identification (first author, title, journal, publication year);

2. Study characteristics (period, country, design);

3. Sample characteristics (stage of breast cancer, sample age, sample ethnicity);

4. Personalized Medicine and Patient centered aspects;

5. Barriers and/or success factors.

\subsection{Quality Assessment}

Three researchers (A.M., R.P., R.P.) independently conducted the methodological quality assessment, based on the different study designs. Disagreements were resolved by discussion with a fourth researcher (C.C.). The standardised critical appraisal tool (1) Scale for the Assessment of Narrative Review Article SANRA [18] was used to assess narrative reviews; (2) Critical Appraisal Skills Programme, CASP [19] for qualitative research; (3) JBI Critical Appraisal Checklist for cohort studies [20]; (4) JBI Critical Appraisal Checklist for text and opinion [21]; (5) The Newcastle-Ottawa Scale NOS for cross-sectional studies [22]; (6) JBI Critical Appraisal Checklist for systematic review and research syntheses [23]. To summarise the overall evidence quality, we decided to cluster the records retrieved into three categories, based on the number of quality criteria met: group 1, studies satisfied at least $75 \%$ of the quality criteria; group 2, studies encountering between $55 \%$ and $74 \%$ of the quality criteria; and group 3, studies met less than $55 \%$ of the quality criteria.

\section{Results}

A total of 1885 records were collected from all the databases searched. After removing duplicates, the remaining 1806 articles were screened by title and abstract. The full texts of the 83 retained papers were screened. Of these, 25 met the eligibility criteria and were included in the systematic review and in the qualitative analysis.

The process of study screening and selection is reported in Figure 1. 


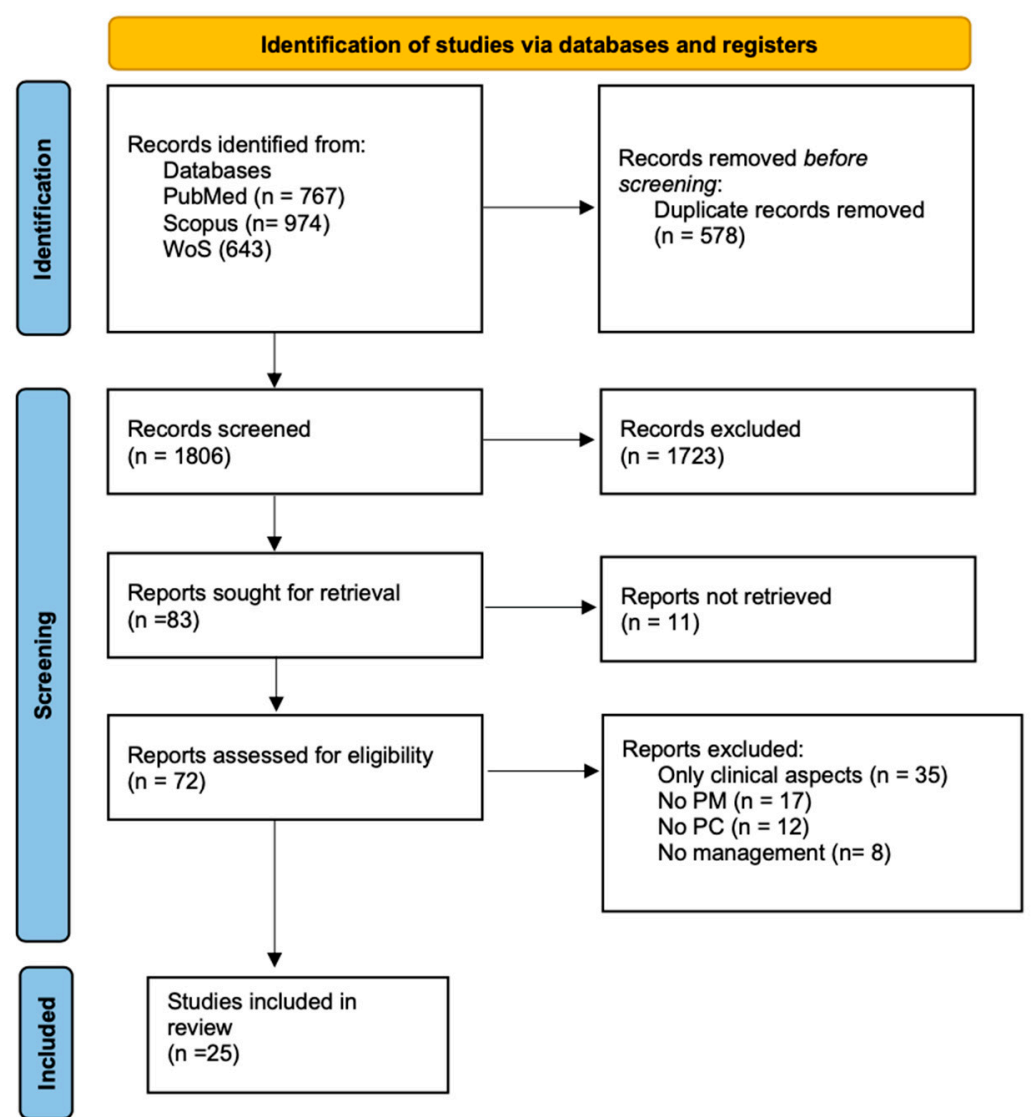

Figure 1. PRISMA Flowchart of the literature review and selection process for breast cancer management in terms of patient-centered care and personalized medicine approaches.

\subsection{Results of Quality Assessment}

The majority of the included articles were narrative reviews [24-32] (36\%) and qualitative researches [33-39] (28\%). As reported in Table 1, six [24,25,27,34,40,41] out of 25 articles (24\%) were classified in group 1 , since they satisfied at least $75 \%$ of the quality criteria, while the majority-11 [26,31,33,35,37-39,42-45] out of 25 articles (44\%) - were allocated in group 2, meeting between $55 \%$ and $74 \%$ of the quality criteria. Lastly, 8 [28-30,32,36,46-48] out of 25 studies (32\%) were inserted in group 3, satisfying less than $55 \%$ of the quality criteria.

Table 1. Summary results of quality assessment.

\begin{tabular}{lcc}
\hline \multicolumn{1}{c}{ Study } & Overall \% & Quality \\
\hline Biganzoli et al. 2017 [27] & $83 \%$ & Group 1 \\
Fountzilas et al. 2018 [25] & $83 \%$ & Group 1 \\
Rosa 2015 [24] & $83 \%$ & Group 1 \\
Jacobs et al. 2017 [40] & $90 \%$ & Group 1 \\
Weldon et al. 2012 [34] & $90 \%$ & Group 1 \\
Zardavas et al. 2013 [41] & $83 \%$ & Group 1 \\
Cowppli-Bony et al. 2019 [42] & $60 \%$ & Group 2 \\
Powis et al. 2017 [44] & $60 \%$ & Group 2 \\
Wallerstedt et al. 2020 [45] & $55 \%$ & Group 2 \\
Saini et al. 2019 [31] & $67 \%$ & Group 2 \\
Schnapper et al. 2018 [37] & $70 \%$ & Group 2 \\
Komatsu et al. 2014 [39] & $70 \%$ & Group 2 \\
McGowan et al. 2016 [33] & $60 \%$ & Group 2 \\
Wright et al. 2019 [35] & $60 \%$ & Group 2 \\
\hline
\end{tabular}


Table 1. Cont.

\begin{tabular}{lcc}
\hline \multicolumn{1}{c}{ Study } & Overall \% & Quality \\
\hline Kurian et al. 2017 [38] & $60 \%$ & Group 2 \\
Kurian et al. 2015 [43] & $67 \%$ & Group 2 \\
Trivedi et al. 2019 [26] & $58 \%$ & Group 2 \\
Tischler et al. 2019 [29] & $42 \%$ & Group 3 \\
Girotra et al. 2016 [30] & $42 \%$ & Group 3 \\
Lyman et al. 2013 [28] & $33 \%$ & Group 3 \\
Laronga et al. 2012 [32] & $50 \%$ & Group 3 \\
Roberts et al. 2016 [36] & $30 \%$ & Group 3 \\
van Hoeve et al. 2014 [48] & $27 \%$ & Group 3 \\
Al-Naqqash 2020 [46] & $45 \%$ & Group 3 \\
Perez 2011 [47] & $33 \%$ & Group 3 \\
\hline
\end{tabular}

\subsection{Outcome Categories}

Below, we report findings relative to the key dimensions of Patient Centered Care and Personalized Medicine, alongside relative key success factors and barriers as shown in Table 2.

\subsubsection{Patient-Centered Care Key Dimensions}

The patient-centered care category included five $[27,36,37,42,44]$ out of twenty-five articles (20\%). Findings relative to the key dimensions were:

- Communication: the description and analysis of communicative skills of clinicians [36] $(20 \%)$;

- Audit and feedback: the measurement of quality indicators and compliance with the standards proposed by the European Society on Breast Cancer Specialists (EUSOMA) $[27,42](40 \%)$;

- Informative systems: their utility and effectiveness for management of cancer-related data [37] (20\%);

- Evidence-based application (guidelines, critical pathway, and procedures): the improvement of patients outcome required necessarily the adherence to the guidelines $[42,44](40 \%)$.

\subsubsection{Personalized Medicine Key Dimensions}

Eleven $[24,28,30,32-35,41,43,45,46]$ out of twenty-five articles (44\%) provided information on personalized medicine for the treatment of breast cancer. Results about key dimensions were:

- Molecular board (compositions and conditions for efficacy): the role, responsibilities and tasks of all members, in particular pathologists and surgeons [24,28,32,33,35] $(45 \%)$;

- Evidence-based genetic testing: the benefits and clinical validity of -omics technologies, focusing on BRCA and Oncotype DX [24,30,32,34,35,41,43,45,46] (82\%);

- Shared-clinical decision-making: a positive impact on the selection of targeted therapy and improvements in chemotherapy, endocrine, and chemo-endocrine therapy decisions $[24,30,32,34,35,41,43,45,46](82 \%)$.

Only three $[24,32,35]$ out of eleven articles $(27 \%)$ provided information on all three dimensions, indicating that the combination of these would be necessary and essential to ensure a more accurate and efficacy targeted treatment. 


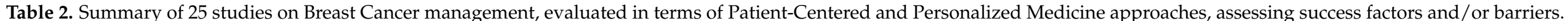
Articles are listed in study design order.

\begin{tabular}{|c|c|c|c|c|c|c|c|c|}
\hline Study & Country & Study Design & $\begin{array}{c}\text { Sample } \\
\text { (Ethnicity/Age) }\end{array}$ & Type of BC & PM or/and PC & Dimensions Involved & Barriers & Success Factors \\
\hline $\begin{array}{c}\text { Van Hoeve et al. } \\
2014\end{array}$ & The Netherlands & Cohort & NA & Primary BC & Both & $\begin{array}{c}\text { Evidence based genetic } \\
\text { testing } \\
\text { (Shared) clinical } \\
\text { decision-making } \\
\text { Audit/feedback } \\
\text { Evidence based application }\end{array}$ & $\begin{array}{l}\text { Lack of clinicians' } \\
\text { involvement in } \\
\text { critical pathways' } \\
\text { construction }\end{array}$ & $\begin{array}{l}\text { Data-derived } \\
\text { benchmarking for } \\
\text { quality } \\
\text { improvements }\end{array}$ \\
\hline $\begin{array}{l}\text { Cowppli-Bony et al. } \\
2019\end{array}$ & France & Cross-sectional & Median age 61 & $\begin{array}{l}\text { Primary invasive } \\
\text { non-metastatic BC }\end{array}$ & PC & $\begin{array}{c}\text { Audit/feedback } \\
\text { Evidence based application }\end{array}$ & $\begin{array}{c}\text { Heterogeneous } \\
\text { adherence to } \\
\text { guidelines among } \\
\text { facilities }\end{array}$ & $\begin{array}{c}\text { Data-derived } \\
\text { benchmarking for } \\
\text { quality } \\
\text { improvements }\end{array}$ \\
\hline Al-Naqqash 2020 & Iraq & $\begin{array}{l}\text { Prospective cohort } \\
\text { study }\end{array}$ & Mean age 54 & $\begin{array}{l}\text { Grade I or grade II } \\
\text { cancer, and } \\
\text { HER2 negative } \\
\text { status }\end{array}$ & PM & $\begin{array}{c}\text { Evidence based genetic } \\
\text { testing } \\
\text { (Shared) clinical } \\
\text { decision-making }\end{array}$ & $\begin{array}{l}\text { Lack of public } \\
\text { reimbursement } \\
\text { scheme for } \\
\text { diagnostics in study } \\
\text { context } \\
\text { Scarce adherence to } \\
\text { guidelines }\end{array}$ & \\
\hline Powis et al. 2017 & Canada & $\begin{array}{l}\text { Retrospective } \\
\text { analysis }\end{array}$ & Age $\geq 65$ years & Early-stage BC & PC & Evidence based application & $\begin{array}{c}\text { Lack of } \\
\text { standardization in } \\
\text { treatment and } \\
\text { clinical practice }\end{array}$ & $\begin{array}{c}\text { Data-derived } \\
\text { benchmarking for } \\
\text { quality } \\
\text { improvements }\end{array}$ \\
\hline McGowan et al. 2016 & USA & Qualitative study & Median age 54 & Advanced BC & PM & Molecular board & $\begin{array}{c}\text { Insufficient } \\
\text { integration and } \\
\text { engagement of } \\
\text { geneticist in MGTB } \\
\text { and in counselling } \\
\text { Lack of } \\
\text { geneticist-patient } \\
\text { relationship }\end{array}$ & $\begin{array}{l}\text { Multi-professional } \\
\text { and multi-specialist } \\
\text { collaboration }\end{array}$ \\
\hline
\end{tabular}


Table 2. Cont

\begin{tabular}{|c|c|c|c|c|c|c|c|c|}
\hline Study & Country & Study Design & $\begin{array}{c}\text { Sample } \\
\text { (Ethnicity/Age) }\end{array}$ & Type of BC & PM or/and PC & Dimensions Involved & Barriers & Success Factors \\
\hline Weldon et al. 2012 & USA & Qualitative study & NA & Any & PM & $\begin{array}{c}\text { Evidence based genetic } \\
\text { testing } \\
\text { (Shared) clinical } \\
\text { decision-making }\end{array}$ & $\begin{array}{l}\text { Lack of public } \\
\text { reimbursement } \\
\text { scheme for } \\
\text { diagnostics in study } \\
\text { context } \\
\text { Poor timing and } \\
\text { seguencing of test } \\
\text { relative to decisions } \\
\text { Counterincentives to } \\
\text { appropriate use of } \\
\text { genetic test }\end{array}$ & $\begin{array}{c}\text { Stakeholders' } \\
\text { collaboration with a } \\
\text { larger role for patient } \\
\text { advocates }\end{array}$ \\
\hline Wright et al. 2019 & UK & Qualitative study & NA & Any & PM & $\begin{array}{c}\text { Molecular board } \\
\text { Evidence based genetic } \\
\text { testing } \\
\text { (Shared) clinical } \\
\text { decision-making }\end{array}$ & & $\begin{array}{l}\text { Clear allocation of } \\
\text { tasks between } \\
\text { oncologists and } \\
\text { geneticists }\end{array}$ \\
\hline Roberts et al. 2016 & North Carolina & Qualitative study & NA & $\begin{array}{c}\text { Early stage, } \\
\text { hormone receptor } \\
\text { positive BC, with } \\
\text { lymph node } \\
\text { negative or lymph } \\
\text { node positive } \\
\text { disease }\end{array}$ & PC & Communication & $\begin{array}{l}\text { Patients excluded } \\
\text { from choices } \\
\text { regarding genetic } \\
\text { tests }\end{array}$ & $\begin{array}{l}\text { Communication } \\
\text { with patients tailored } \\
\text { to their needs and } \\
\text { background }\end{array}$ \\
\hline Schnapper et al. 2018 & Italy & Qualitative study & NA & Any & PC & Informative systems & $\begin{array}{c}\text { Non-uniform } \\
\text { professional profile } \\
\text { of DM at EU level }\end{array}$ & \\
\hline Kurian et al. 2017 & USA & Qualitative study & $\begin{array}{c}\text { Black, Asian, } \\
\text { Hispanic and white } \\
\text { women age } 20 \text { to } \\
79 \text { years }\end{array}$ & Early-stage BC & Both & $\begin{array}{c}\text { Evidence based genetic } \\
\text { testing } \\
\text { Communication } \\
\text { (Shared) clinical } \\
\text { decision-making }\end{array}$ & $\begin{array}{c}\text { Insufficient } \\
\text { integration and } \\
\text { engagement of } \\
\text { geneticist in } \\
\text { counseling } \\
\text { Cost barriers to } \\
\text { effective testing } \\
\text { despite price } \\
\text { reduction }\end{array}$ & $\begin{array}{l}\text { Communication } \\
\text { with patients tailored } \\
\text { to their needs and } \\
\text { background }\end{array}$ \\
\hline
\end{tabular}


Table 2. Cont.

\begin{tabular}{|c|c|c|c|c|c|c|c|c|}
\hline Study & Country & Study Design & $\begin{array}{c}\text { Sample } \\
\text { (Ethnicity/Age) }\end{array}$ & Type of BC & PM or/and PC & Dimensions Involved & Barriers & Success Factors \\
\hline Komatsu et al. 2014 & Japan & Qualitative study & NA & Any & Both & $\begin{array}{c}\text { Evidence based genetic } \\
\text { testing } \\
\text { Communication } \\
\text { Informative system } \\
\text { Multidisciplinary approach }\end{array}$ & $\begin{array}{l}\text { Delay in adoption of } \\
\text { new technologies in } \\
\text { clinical practice } \\
\text { Fragmented } \\
\text { communication of } \\
\text { genetic data among } \\
\text { multidisciplinary } \\
\text { professionals }\end{array}$ & $\begin{array}{l}\text { Education and } \\
\text { training on genetic } \\
\text { testing also among } \\
\text { non-geneticists }\end{array}$ \\
\hline Kurian 2015 & & Invited Commentary & NA & Any & $\mathrm{PM}$ & $\begin{array}{c}\text { Evidence based genetic } \\
\text { testing } \\
\text { (Shared) clinical } \\
\text { decision-making }\end{array}$ & & $\begin{array}{c}\text { Shared } \\
\text { decision-making } \\
\text { between patients } \\
\text { and clinicians } \\
\end{array}$ \\
\hline Rosa 2015 & USA & Narrative review & NA & Any & $\mathrm{PM}$ & $\begin{array}{c}\text { Molecular board } \\
\text { Evidence based genetic } \\
\text { testing } \\
\text { (Shared) clinical } \\
\text { decision-making }\end{array}$ & & $\begin{array}{l}\text { Patologists' } \\
\text { knowledge on } \\
\text { genetic test }\end{array}$ \\
\hline Fountzilas et al. 2018 & & Narrative review & NA & Any & Both & $\begin{array}{c}\text { Evidence based genetic } \\
\text { testing } \\
\text { Multidisciplinary approach }\end{array}$ & & $\begin{array}{l}\text { Education and } \\
\text { training on genetic } \\
\text { testing }\end{array}$ \\
\hline Trivedi et al. 2019 & & Narrative review & NA & Any & Both & $\begin{array}{c}\text { Molecular board } \\
\text { Evidence based genetic } \\
\text { testing } \\
\text { Multidisciplinary approach }\end{array}$ & & $\begin{array}{l}\text { Multiprofessional } \\
\text { and multispecialist } \\
\text { collaboration }\end{array}$ \\
\hline Biganzoli et al. 2017 & & Narrative review & NA & Any & PC & Audit/feedback & $\begin{array}{l}\text { Lack of outcome } \\
\text { indicators }\end{array}$ & \\
\hline Lyman et al. 2013 & & Narrative review & NA & Any & $\mathrm{PM}$ & Molecular board & & $\begin{array}{l}\text { Multiprofessional } \\
\text { and multispecialist } \\
\text { collaboration }\end{array}$ \\
\hline
\end{tabular}


Table 2. Cont.

\begin{tabular}{|c|c|c|c|c|c|c|c|c|}
\hline Study & Country & Study Design & $\begin{array}{c}\text { Sample } \\
\text { (Ethnicity/Age) }\end{array}$ & Type of BC & PM or/and PC & Dimensions Involved & Barriers & Success Factors \\
\hline Tischler et al. 2019 & & Narrative review & NA & Any & Both & $\begin{array}{c}\text { Evidence based genetic } \\
\text { testing } \\
\text { (Shared) clinical } \\
\text { decision-making } \\
\text { Communication } \\
\text { Multidisciplinary approach }\end{array}$ & $\begin{array}{l}\text { Scarse diffusion of } \\
\text { unique vocabulary } \\
\text { to guide therapy } \\
\text { strategies }\end{array}$ & $\begin{array}{l}\text { Utilization of } \\
\text { personalized } \\
\text { medicine prevention } \\
\text { techniques }\end{array}$ \\
\hline Girotra et al. 2016 & & Narrative review & NA & Any & $\mathrm{PM}$ & $\begin{array}{c}\text { Evidence based genetic } \\
\text { testing } \\
\text { (Shared) clinical } \\
\text { decision-making }\end{array}$ & & $\begin{array}{c}\text { Utilization of } \\
\text { personalized } \\
\text { medicine prevention } \\
\text { techniques }\end{array}$ \\
\hline Geetanjali et al. 2019 & & Narrative review & NA & Any & Both & $\begin{array}{c}\text { Evidence based genetic } \\
\text { testing } \\
\text { (Shared) clinical } \\
\text { decision-making } \\
\text { Multidisciplinary approach }\end{array}$ & $\begin{array}{l}\text { Dynamicity of } \\
\text { genomic data } \\
\text { generation and } \\
\text { gathering }\end{array}$ & $\begin{array}{l}\text { Multiprofessional } \\
\text { and multispecialist } \\
\text { collaboration }\end{array}$ \\
\hline Laronga et al. 2012 & & Narrative review & NA & $\begin{array}{l}\text { Newly diagnosed, } \\
\text { estrogen receptor } \\
\text { (ER)-positive, } \\
\text { node-negative, } \\
\text { early-stage BC } \\
\text { treated with } \\
\text { endocrine therapy }\end{array}$ & $\mathrm{PM}$ & $\begin{array}{c}\text { Molecular board } \\
\text { Evidence based genetic } \\
\text { testing } \\
\text { (Shared) clinical } \\
\text { decision-making }\end{array}$ & & $\begin{array}{l}\text { Multiprofessional } \\
\text { and multispecialist } \\
\text { collaboration }\end{array}$ \\
\hline Zardavas 2013 & & Review & NA & Any & PM & $\begin{array}{c}\text { Evidence based genetic } \\
\text { testing } \\
\text { (Shared) clinical } \\
\text { decision-making }\end{array}$ & $\begin{array}{l}\text { Lack of systematic } \\
\text { approach to the } \\
\text { adoption of new } \\
\text { technologies in } \\
\text { clinical practice }\end{array}$ & $\begin{array}{l}\text { Creation of unique } \\
\text { vocabulary to guide } \\
\text { therapy strategies }\end{array}$ \\
\hline Perez 2011 & USA & Review & NA & Any & Both & $\begin{array}{c}\text { Molecular board } \\
\text { Evidence based genetic } \\
\text { testing } \\
\text { Multidisciplinary approach }\end{array}$ & $\begin{array}{l}\text { Evidence based on } \\
\text { evaluation of } \\
\text { personalized } \\
\text { medicine only for } \\
\text { primary breast } \\
\text { cancer }\end{array}$ & $\begin{array}{l}\text { Multiprofessional } \\
\text { and multispecialist } \\
\text { collaboration }\end{array}$ \\
\hline $\begin{array}{l}\text { Wallerstedt et al. } \\
2020\end{array}$ & Sweden & Systematic review & NA & Post-surgical BC & $\mathrm{PM}$ & $\begin{array}{c}\text { Evidence based genetic } \\
\text { testing } \\
\text { (Shared) clinical } \\
\text { decision-making }\end{array}$ & $\begin{array}{c}\text { Lack of evidence of } \\
\text { therapy effects on } \\
\text { HRQL }\end{array}$ & $\begin{array}{c}\text { Utilization of } \\
\text { personalized } \\
\text { medicine prevention } \\
\text { techniques }\end{array}$ \\
\hline
\end{tabular}

\footnotetext{
Legend: NA, not applicable; BC, breast cancer; PM, personalized medicine; PC, patient centered; Early BC, stage 0- I-II. Country is not specified for Invited Commentary, Narrative review and one review.
} 


\subsubsection{Key Dimensions for Applying Personalized Medicine and Patient-Centered Care}

Nine $[25,26,29,31,38-40,47,48]$ out of twenty-five articles (36\%) reported information on both categories (PM and PC).

In particular, two $[40,47]$ out of nine articles $(22 \%)$ referred to the molecular board; eight $[25,26,29,31,38,39,47,48](89 \%)$ referred to evidence-based genetic testing.

Information on shared-clinical decision-making was reported by six $[26,29,31,38,47,48]$ (66\%): in particular, only one [31] described and analyzed several web supports to include the patient in the decision-making process.

Four [29,38-40] $(44 \%)$ referred to communication, focusing on a greater sharing of information during genetic counselling.

One [48] (11\%) referred to audit/feedback and two [26,39] (22\%) to informative systems. Both agreed on the introduction of scientific tools, such as electronic medical records (EMR), to combine clinical and genomic data.

Evidence-based application was described by only one study [48] (11\%), with the implementation of an integrated oncology clinical pathway model (IOCP).

Seven $[25,26,29,31,39,40,47](78 \%)$ referred to a multidisciplinary approach: most of them agreed on the need for education and training programs about genetic testing for all members of the multidisciplinary team.

\subsection{Success Factors and Barriers in the Management of Breast Cancer Pathway \\ 3.3.1. Success Factors}

Analysis of the included articles revealed the following key success factors of the enactment of personalized treatment and patient-centered care models in BC clinical practice, which can be summarized as follows: multiprofessional/multispecialist collaboration; education and training on genetic testing; utilization of personalized medicine prevention techniques; clear communication between clinicians and patients; data derived benchmarking for quality improvement.

More specifically, appropriately training and assembling multi-professional and multi-specialist teams is described as an organizational strength for the treatment of BC $[26,28,31-33,47]$. In breast oncology practice, in fact, the team must necessarily include qualified specialists to bridge the gap between clinical knowledge and genetic potential, especially able to collect and evaluate genomic profiling data [31,33]. The importance of refining clinicians' training on genetic testing and communication strategies is also linked to clinician-to-patient communication [36,38]: a communicative approach focused on patients and their background consent a better involvement of them in the decision-making process [43]. In addition, measuring and benchmarking the performance of clinical pathways through quality indicators allow us to identify, on one side, weak areas that require improvement and, on the other, those which adhered to clinical guidelines [42,44,48].

Lastly, another key success factor is found in the appropriateness of the genetic test selection process, which must take into account clinical utility and validity, analytical validity, as well as ethical, legal, and social implications [25].

\subsubsection{Barriers}

Our records allowed us to identify some general barriers that should be improved and overcome in the future, such as the lack of a universal language among health professionals, the uncertain composition of multidisciplinary teams and delays in the adoption of new technologies in clinical practice.

The need for proper training and education for geneticists and clinicians $[24,25,39]$ is not supported by the adoption of a universal genomics vocabulary [41]. Additionally, the unclear definition of the scope of the genetic counseling — or an insufficiently involved geneticistrepresents a barrier to proper and adequate communication with the patient [33,38]. From here, the need to define the role of genetic counseling through internal protocols, both before and after the execution of the tests, also serves as a barrier [40]. 
Moreover, there seems to be lack of clarity on the allocation of tasks and responsibilities among all members of the multidisciplinary team. Especially between oncologists and geneticists, the administration, interpretation and use of genetic tests and -omics technologies are fragmented [35], further confirming the importance of introducing new professional profiles trained and responsible for data collection and analysis, such as data manager [37].

The delay in the adoption of -omic technologies in clinical practice is associated to the lack of clarity in their appropriate timing and use $[39,41,44]$. Furthermore, the insufficient use of genetic testing is linked to the absence of public reimbursement schemes which disincentivizes their utilization $[34,46]$.

\section{Discussion}

Authors should discuss the results and how they can be interpreted from the perspective of previous studies and of the working hypotheses. The findings and their implications should be discussed in the broadest context possible. Future research directions may also be highlighted.

We systematically reported on the state-of-the-art of available literature investigating the enactment of personalized treatment and patient-centered care models in BC clinical practice. We also aimed at highlighting the key success factors of such a shift, alongside relative barriers to implementation. The main success factors found in our included articles are the clear definition of roles and responsibilities within a multi-professional collaboration, backed by appropriate training and education programs. Last but not least, there is the need for an adequate communication strategy which includes the adoption of a universal genomic language and the active involvement of the patient in the decision-making process. Overall, it appears that -omics technology cannot rely on a solid organizational structure, neither at the micro level of single facilities or at the macro level of the health system. Compared to El-Alti et al. 2019 [49], which questions whether the relationship between personalized medicine and patient-centered care is a complementary or mutually exclusive one, our study takes a step further and answers the question by supporting the thesis by which these models are indeed synergically complementary.

In fact, PM alone is not sufficient to select the best treatment choice as it focuses mainly on somatic, biological and genetic features of the patient. It is here that the role played by Patient Centered Care ensures the active engagement of the patient by bringing his personal needs and preferences into the decision-making process. Nardini et al. 2021 [50] describe a new healthcare configuration that includes personalized, predictive, preventive, participatory and person-centered care approaches, to be applied to all areas of medicine. Agreeing with such findings, this review recognizes how both models together are needed to ensure a positive and effective change in the path of patient care and attempts to tailor such a transition to the context of breast cancer care.

With the next step being the delivery of personalized care, it becomes central to find solutions to the array of organizational challenges that come with it to allow, on one side, the high degree of specialization, scientific-technical advances and multidisciplinary and multiprofessional coordination, and, on the other, patient participation and the ability to respond to multiple care needs [51].

Internationally, clinical pathways have been recognized as a suitable tool to drive care towards patient-centeredness, and result from a translation of Evidence Based Medicine (EBM) principles into localized contexts (Figure 2), as a strategy to reduce unnecessary clinical variability, costs, fragmentation of care improving outcomes and quality of care [52]. However, it has been argued that committing to one or a few best recommendations and standards may slow down the pace of change in the landscape of oncological care and prevent providers and professionals from being able to deliver individualized treatments that synergize with patient preferences [53]. 


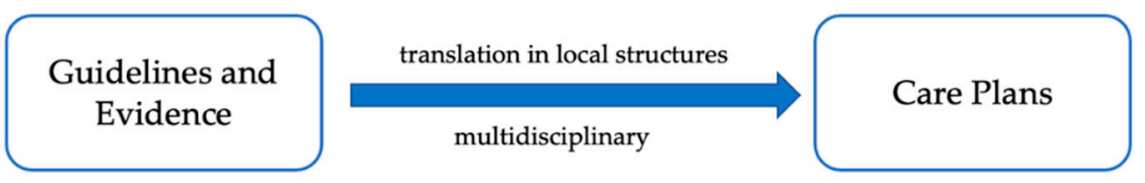

Figure 2. The "classic" clinical pathway on breast cancer.

It is in the recognition of such limitations that it becomes necessary to bring personalized medicine into clinical practice by rendering it an integral part of clinical pathways. Their nature, in fact, allows for merging the ultimate therapeutic advancements and best current evidence with individual patient characteristics and preferences, while still attenuating unnecessary clinical variability.

Typically, patient preferences are left out in the construction process of the "classic Clinical Pathway model" as they are not considered among principal factors. However, when therapeutic options may lead to different results depending on patients' preferences, patients' participation in the decision-making process is a keystone of high-quality cancer care. Shared Decision-Making (SDM) can be defined as "an approach where physicians and patients share the best available evidence when faced with the task of making treatment decisions, and where patients are supported to consider options, to achieve informed preferences [54], with positive effects on patient satisfaction cost effectiveness and the number of malpractice lawsuits" [55-57] (Maes-Carballo et al., 2020) [58].

In light of the above, the BC Clinical Pathway constitutes an ideal context in which to set-up a SDM system as shown in Figure 3 that allows for a transformation of the standardized application of EBM (Figure 2) into a dynamic and personalized care pathway.

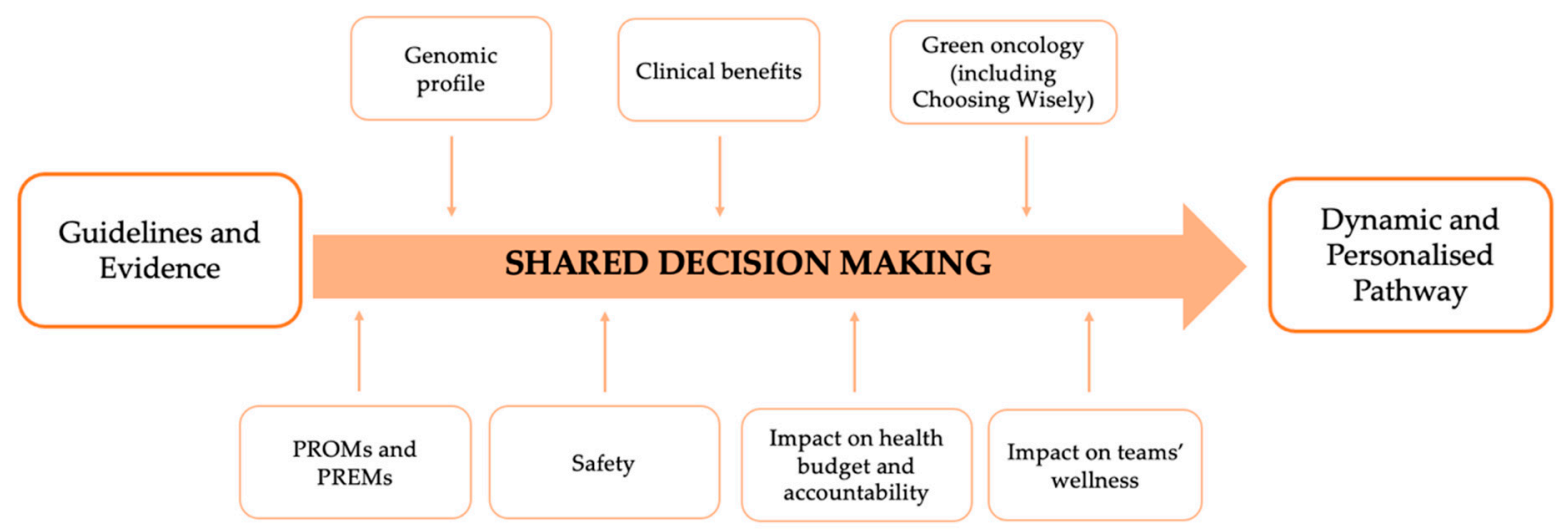

Figure 3. The personalized pathway on breast cancer.

Structuring the pathway on specific moments of shared decision making-to be applied not only between patients and healthcare professionals, but also between healthcare professionals themselves; our model blends personalized medicine and patient centered care determinants, such as each patients' genetic features (i.e., the genomic profile), impacts on the patient's health status (including patient safety and treatment adverse effects) and patient reported measures (PROMs and PREMs).

Additionally, however, following the direction taken by Value-Based Healthcare and, in particular Bodenheimer's Quadruple-Aim framework [59], the next generation of care pathway's framework must include also other three dimensions: at an organizational micro level, the framework considers care-team sharing, being a determinant of team wellness; at a macro-organizational level, the principles of green oncology, waste containment and impacts on overall budget and accountability, to evaluate the broadest impact possible of the dynamic pathway. 


\section{Limitations}

There are some limitations in this systematic review that should be taken into account when interpreting the results. First of all, broadly speaking, evidence in the current literature of primary studies clearly defining the combined use of personalized medicine and patient-centered care approaches were quite scarce. Secondly, heterogeneity in study designs, in outcome definition and in staging systems adopted (often not at all present in the included studies) prevented us from conducting a meta-analysis and issuing more conclusive results. Furthermore, according to the adopted quality assessment tools, most of the included studies were of moderate-poor quality.

\section{Conclusions}

In the last few years, patient-centered care has been found to be one of the key elements for improving the quality of breast cancer management. Clinical-care-pathways, especially oncological ones, have certainly contributed to the transparency of the decisionmaking process. The pressure that personalized medicine is placing in the field of oncology, however, highlights the need to structure organizational models that combine PC care models and PM together. The sustainability of the model proposed in this work would largely benefit from further developments and confirmations through additional research, as well as in ulterior organizational contexts.

Author Contributions: Study conception and design: A.G.d.B., R.P. (Roberta Pastorino); data collection: C.C., A.M., R.P. (Rossella Pellegrino); analysis and interpretation of results: C.C., A.M., R.P. (Roberta Pastorino), R.P. (Rossella Pellegrino); draft manuscript preparation: A.G.d.B., C.C., A.M., R.P. (Rossella Pellegrino); supervision and revision: S.B., A.G.d.B., R.P. (Roberta Patorino). All authors reviewed the results. All authors have read and agreed to the published version of the manuscript.

Funding: This research received no external funding.

Institutional Review Board Statement: Not applicable.

Informed Consent Statement: Not applicable.

Data Availability Statement: Not applicable.

Conflicts of Interest: The authors declare conflict of interest: Rossella Pellegrino's work was funded through an unconditioned grant by Daiichi-Sankyo. The funders had no role in the design of the study; in the collection, analyses, or interpretation of data; in the writing of the manuscript, or in the decision to publish the results.

\section{References}

1. Sung, H.; Ferlay, J.; Siegel, R.L.; Laversanne, M.; Soerjomataram, I.; Jemal, A.; Bray, F. Global cancer statistics 2020: GLOBOCAN estimates of incidence and mortality worldwide for 36 cancers in 185 countries. CA Cancer J. Clin. 2021, 71, 209-249. [CrossRef] [PubMed]

2. Shao, J.; Rodrigues, M.; Corter, A.L.; Baxter, N.N. Multidisciplinary Care of Breast Cancer Patients: A Scoping Review of Multidisciplinary Styles, Processes, and Outcomes. Curr. Oncol. 2019, 26, 385-397. [CrossRef]

3. Cardoso, F.; Cataliotti, L.; Costa, A.; Knox, S.; Marotti, L.; Rutgers, E.; Beishon, M. European Breast Cancer Conference manifesto on breast centres/units. Eur. J. Cancer 2017, 72, 244-250. [CrossRef]

4. Franceschini, G.; Di Leone, A.; Masetti, R. The Breast Unit Update on advantages and the open issues. Ann. Ital. Chir. 2014, $85,407-412$.

5. Chan, C.W.H.; Law, B.M.H.; So, W.K.W.; Chow, K.M.; Waye, M.M.Y. Novel Strategies on Personalized Medicine for Breast Cancer Treatment: An Update. Int. J. Mol. Sci. 2017, 18, 2423. [CrossRef]

6. Cardoso, F.; Senkus, E.; Costa, A.; Papadopoulos, E.; Aapro, M.; Andre, F.; Harbeck, N.; Lopez, B.A.; Barrios, C.; Bergh, J.; et al 4th ESO-ESMO International Consensus Guidelines for Advanced Breast Cancer (ABC 4). Ann. Oncol. 2018, 29, $1634-1657$. [CrossRef] [PubMed]

7. Page, M.J.; McKenzie, J.; Bossuyt, P.; Boutron, I.; Hoffmann, T.; Mulrow, C.; Shamseer, L.; Tetzlaff, J.; Akl, E.; Brennan, S.; et al. The PRISMA 2020 Statement: An Updated Guideline for Reporting Systematic Reviews. 2020. Available online: https: / / osf.io/preprints/metaarxiv/v7gm2/ (accessed on 19 May 2021).

8. EUR-Lex. C:2015:421:FULL. Available online: https://eur-lex.europa.eu/legal-content/EN/TXT/?uri=OJ\%3AC\%3A2015\%3A4 21\%3AFULL (accessed on 25 May 2021). 
9. Medicine I of Crossing the Quality Chasm: A New Health System for the 21st Century. 2001. Available online: https:/ www.nap. edu/catalog/10027/ crossing-the-quality-chasm-a-new-health-system-for-the (accessed on 19 May 2021).

10. Naughton, C.A. Patient-Centered Communication. Pharmacy 2018, 6, 18. [CrossRef] [PubMed]

11. Rotter, T.; Kinsman, L.; James, E.L.; Machotta, A.; Gothe, H.; Willis, J.; Snow, P.; Kugler, J. Clinical pathways: Effects on professional practice, patient outcomes, length of stay and hospital costs. Cochrane Database Syst. Rev. 2010, CD006632. [CrossRef]

12. Yazdanian, A.; Ayatollahi, H.; Nahvijou, A. Oncology Information System: A Qualitative Study of Users' Requirements. Asian Pac. J. Cancer Prev. 2019, 20, 3085-3091. [CrossRef]

13. Melnyk, B.M.; Fineout-Overholt, E. Evidence-Based Practice in Nursing \& Healthcare: A Guide to Best Practice; Lippincott Williams \& Wilkins: Philadelphia, PA, USA, 2011; 530p.

14. Horvath, L.E.; Yordan, E.; Malhotra, D.; Leyva, I.; Bortel, K.; Schalk, D.; Mellinger, P.; Huml, M.; Kesslering, C.; Huml, J. Multidisciplinary Care in the Oncology Setting: Historical Perspective and Data from Lung and Gynecology Multidisciplinary Clinics. J. Oncol. Pract. 2010, 6, e21-e26. [CrossRef]

15. Koopman, B.; Groen, H.J.; Ligtenberg, M.J.; Grünberg, K.; Monkhorst, K.; De Langen, A.J.; Boelens, M.C.; Paats, M.S.; Von Der Thüsen, J.H.; Dinjens, W.N.; et al. Multicenter Comparison of Molecular Tumor Boards in The Netherlands: Definition, Composition, Methods, and Targeted Therapy Recommendations. Oncologist 2020. [CrossRef]

16. Pagon, R.A.; Hanson, N.B.; Neufeld-Kaiser, W.; Covington, M.L. Genetic testing. West. J. Med. 2001, 174, 344-347. [CrossRef]

17. Shared Decision Making. Available online: https://www.healthit.gov/sites/default/files/nlc_shared_decision_making_fact_ sheet.pdf (accessed on 20 May 2021).

18. Baethge, C.; Goldbeck-Wood, S.; Mertens, S. SANRA-A scale for the quality assessment of narrative review articles. Res. Integr. Peer Rev. 2019, 4, 1-7. [CrossRef]

19. Long, H.A.; French, D.P.; Brooks, J.M. Optimising the value of the critical appraisal skills programme (CASP) tool for quality appraisal in qualitative evidence synthesis. Res. Methods Med. Health Sci. 2020, 1, 31-42. [CrossRef]

20. Martin, J. Joanna Briggs Institute 2017 Critical Appraisal Checklist for Cohort Studies; JBI: Adelaide, Australia, 2017.

21. Martin, J. Joanna Briggs Institute 2017 Critical Appraisal Checklist for Text and Opinion; JBI: Adelaide, Australia, 2017.

22. Stang, A. Critical evaluation of the Newcastle-Ottawa scale for the assessment of the quality of nonrandomized studies in meta-analyses. Eur. J. Epidemiol. 2010, 25, 603-605. [CrossRef] [PubMed]

23. Martin, J. Joanna Briggs Institute 2017 Critical Appraisal Checklist for Systematic Reviews and Research Syntheses; JBI: Adelaide, Australia, 2017.

24. Rosa, M. Advances in the Molecular Analysis of Breast Cancer: Pathway toward Personalized Medicine. Cancer Control 2015, 22, 211-219. [CrossRef] [PubMed]

25. Fountzilas, C.; Kaklamani, V.G. Multi-gene Panel Testing in Breast Cancer Management. Cancer Treat. Res. 2018, 173, 121-140. [CrossRef]

26. Trivedi, H.; Kling, H.M.; Treece, T.; Audeh, W.; Srkalovic, G. Changing Landscape of Clinical-Genomic Oncology Practice. Acta Medica Acad. 2019, 48, 6-17. [CrossRef]

27. Biganzoli, L.; Marotti, L.; Hart, C.D.; Cataliotti, L.; Cutuli, B.; Kühn, T.; Mansel, R.E.; Ponti, A.; Poortmans, P.; Regitnig, P.; et al. Quality indicators in breast cancer care: An update from the EUSOMA working group. Eur. J. Cancer 2017, 86, 59-81. [CrossRef]

28. Lyman, G.H.; Baker, J.; Geradts, J.; Horton, J.; Kimmick, G.; Peppercorn, J.; Pruitt, S.; Scheri, R.P.; Hwang, E.S. Multidisciplinary Care of Patients with Early-Stage Breast Cancer. Surg. Oncol. Clin. N. Am. 2013, 22, 299-317. [CrossRef]

29. Tischler, J.; Crew, K.D.; Chung, W.K. Cases in Precision Medicine: The Role of Tumor and Germline Genetic Testing in Breast Cancer Management. Ann. Intern. Med. 2019, 171, 925. [CrossRef] [PubMed]

30. Girotra, S.; Yeghiazaryan, K.; Golubnitschaja, O. Potential biomarker panels in overall breast cancer management: Advancements by multilevel diagnostics. Pers. Med. 2016, 13, 469-484. [CrossRef] [PubMed]

31. Saini, G.; Mittal, K.; Rida, P.; Janssen, E.A.M.; Gogineni, K.; Aneja, R. Panoptic View of Prognostic Models for Personalized Breast Cancer Management. Cancers 2019, 11, 1325. [CrossRef]

32. Laronga, C.; Harness, J.K.; Dixon, M.; Borgen, P.I. The role of the breast cancer surgeon in personalized cancer care: Clinical utility of the 21-gene assay. Am. J. Surg. 2012, 203, 751-758. [CrossRef] [PubMed]

33. McGowan, M.L.; Ponsaran, R.S.; Silverman, P.; Harris, L.N.; Marshall, P.A. "A rising tide lifts all boats": Establishing a multidisciplinary genomic tumor board for breast cancer patients with advanced disease. BMC Med Genom. 2016, 9, 1-10. [CrossRef]

34. Weldon, C.B.; Trosman, J.R.; Gradishar, W.J.; Benson, A.B.; Schink, J.C. Barriers to the Use of Personalized Medicine in Breast Cancer. J. Oncol. Pract. 2012, 8, e24-e31. [CrossRef]

35. Wright, S.; Porteous, M.; Stirling, D.; Young, O.; Gourley, C.; Hallowell, N. Negotiating jurisdictional boundaries in response to new genetic possibilities in breast cancer care: The creation of an 'oncogenetic taskscape'. Soc. Sci. Med. 2019, 225, 26-33. [CrossRef] [PubMed]

36. Roberts, M.C.; Bryson, A.; Weinberger, M.; Dusetzina, S.; Dinan, M.A.; Reeder-Hayes, K.E.; Wheeler, S.B. Patient-Centered Communication for Discussing Oncotype DX Testing. Cancer Investig. 2016, 34, 205-212. [CrossRef]

37. Schnapper, G.; Marotti, L.; Casella, D.; Mano, M.P.; Mansel, R.E.; Ponti, A.; The EUSOMA Breast Centers Network Data Managers. Data managers: A survey of the European Society of Breast Cancer Specialists in certified multi-disciplinary breast centers. Breast J. 2018, 24, 811-815. [CrossRef] 
38. Kurian, A.W.; Li, Y.; Hamilton, A.S.; Ward, K.C.; Hawley, S.T.; Morrow, M.; McLeod, M.C.; Jagsi, R.; Katz, S.J. Gaps in Incorporating Germline Genetic Testing into Treatment Decision-Making for Early-Stage Breast Cancer. J. Clin. Oncol. 2017, 35, 2232-2239. [CrossRef]

39. Komatsu, H.; Yagasaki, K. Are we ready for personalized cancer risk management? The view from breast-care providers. Int. J. Nurs. Pract. 2013, 20, 39-45. [CrossRef]

40. Jacobs, C.; Pichert, G.; Harris, J.; Tucker, K.; Michie, S. Key messages for communicating information about BRCA1 and BRCA2 to women with breast or ovarian cancer: Consensus across health professionals and service users. Psycho-Oncology 2017, 26, 1818-1824. [CrossRef] [PubMed]

41. Zardavas, D.; Pugliano, L.; Piccart, M. Personalized therapy for breast cancer: A dream or a reality? Futur. Oncol. 2013, 9, 1105-1119. [CrossRef]

42. Cowppli-Bony, A.; Trétarre, B.; Marrer, E.; Defossez, G.; Daubisse-Marliac, L.; Coureau, G.; Minicozzi, P.; Woronoff, A.-S.; Delafosse, P.; Molinié, F.; et al. Compliance with clinical guidelines for breast cancer management: A population-based study of quality-of-care indicators in France. PLoS ONE 2019, 14, e0224275. [CrossRef]

43. Kurian, A.W.; Friese, C.R. Precision Medicine in Breast Cancer Care: An Early Glimpse of Impact. JAMA Oncol. 2015, 1, 1109-1110. [CrossRef] [PubMed]

44. Powis, M.; Sutradhar, R.; Gonzalez, A.; Enright, K.A.; Taback, N.A.; Booth, C.M.; Trudeau, M.; Krzyzanowska, M.K. Establishing achievable benchmarks for quality improvement in systemic therapy for early-stage breast cancer. Cancer 2017, 123, 3772-3780. [CrossRef]

45. Wallerstedt, S.M.; Ek, A.N.; Bagge, R.O.; Kovács, A.; Strandell, A.; Linderholm, B. Personalised medicine and the decision to withhold chemotherapy in early breast cancer with intermediate risk of recurrence-A systematic review and meta-analysis. Eur. J. Clin. Pharmacol. 2020, 76, 1199-1211. [CrossRef]

46. Al-Naqqash, M.A. The 21-gene oncotype DX offers more accurate treatment decisions in early breast cancer. Gastric Breast Cancer 2020, 15, 1-7. [CrossRef]

47. Perez, E.A. Breast Cancer Management: Opportunities and Barriers to an Individualized Approach. Oncologist 2011, 16, 20-22. [CrossRef] [PubMed]

48. Van Hoeve, J.; De Munck, L.; Otter, R.; De Vries, J.; Siesling, S. Quality improvement by implementing an integrated oncological care pathway for breast cancer patients. Breast 2014, 23, 364-370. [CrossRef]

49. El-Alti, L.; Sandman, L.; Munthe, C. Person Centered Care and Personalized Medicine: Irreconcilable Opposites or Potential Companions? Health Care Anal. 2017, 27, 45-59. [CrossRef]

50. Nardini, C.; Osmani, V.; Cormio, P.G.; Frosini, A.; Turrini, M.; Lionis, C.; Neumuth, T.; Ballensiefen, W.; Borgonovi, E.; D’Errico, G. The evolution of personalized healthcare and the pivotal role of European regions in its implementation. Pers. Med. 2021, 18, 283-294. [CrossRef]

51. Maes-Carballo, M.; Martín-Díaz, M.; Mignini, L.; Khan, K.; Trigueros, R.; Bueno-Cavanillas, A. Evaluation of the Use of Shared Decision Making in Breast Cancer: International Survey. Int. J. Environ. Res. Public Health 2021, 18, 2128. [CrossRef]

52. Panella, M.; Marchisio, S.; Di Stanislao, F. Reducing clinical variations with clinical pathways: Do pathways work? Int. J. Qual. Health Care 2003, 15, 509-521. [CrossRef] [PubMed]

53. Smeds, M. Managing Care Pathways for Patients with Complex Care Needs; Linköping University Electronic Press: Linköping, Sweden, 2019; Available online: http:/ / urn.kb.se/resolve?urn=urn:nbn:se:liu:diva-156836 (accessed on 20 May 2021).

54. Elwyn, G.; Laitner, S.; Coulter, A.; Walker, E.; Watson, P.; Thomson, R. Implementing shared decision making in the NHS. BMJ 2010, 341, c5146. [CrossRef]

55. Committee on Improving the Quality of Cancer Care: Addressing the Challenges of an Aging Population, Board on Health Care Services, Institute of Medicine. Delivering High-Quality Cancer Care: Charting a New Course for a System in Crisis; Levit, L., Balogh, E., Nass, S., Ganz, P.A., Eds.; National Academies Press (US): Washington, DC, USA, 2013. Available online: http:/ / www.ncbi.nlm.nih.gov/books / NBK202148/ (accessed on 19 May 2021).

56. Elwyn, G.; Frosch, D.; Thomson, R.; Joseph-Williams, N.; Lloyd, A.; Kinnersley, P.; Cording, E.; Tomson, D.; Dodd, C.; Rollnick, S.; et al. Shared Decision Making: A Model for Clinical Practice. J. Gen. Intern. Med. 2012, 27, 1361-1367. [CrossRef] [PubMed]

57. Schoenfeld, E.M.; Mader, S.; Houghton, C.; Wenger, R.; Probst, M.A.; Schoenfeld, D.A.; Lindenauer, P.K.; Mazor, K.M. The Effect of Shared Decisionmaking on Patients' Likelihood of Filing a Complaint or Lawsuit: A Simulation Study. Ann. Emerg. Med. 2019, 74, 126-136. [CrossRef]

58. Maes-Carballo, M.; Muñoz-Núñez, I.; Martín-Díaz, M.; Mignini, L.; Bueno-Cavanillas, A.; Khan, K.S. Shared decision making in breast cancer treatment guidelines: Development of a quality assessment tool and a systematic review. Health Expect. 2020, 23, 1045-1064. [CrossRef] [PubMed]

59. Bodenheimer, T.; Sinsky, C. From Triple to Quadruple Aim: Care of the Patient Requires Care of the Provider. Ann. Fam. Med. 2014, 12, 573-576. [CrossRef] 